\title{
The Analysis of FDI's impact on Foreign Trade between China and Pakistan
}

\author{
Shushu Feng \\ International Business School \\ Yunnan University of Finance and Economics \\ Kunming, Yunnan, China \\ shushufeng@gmail.com
}

\begin{abstract}
Pakistan is a long term strategic partner and long time friend of China. Under the background of $B \& R$ Initiative and China Pakistan Economic Corridor, it is critical to improve the economic cooperation and investment cooperation between two countries. This paper will summarize the status quo of China's FDI in Pakistan after 5 years of the construction of China Pakistan Economic Corridor. Then a empirical study will be done to see FDI's impact on trade in the short and long term between China and Pakistan. It is concluded that FDI's impact on trade is more significant in the long run, and that promoting effect is better for import than export.
\end{abstract}

\section{Keywords-FDI; foreign trade; sino-pakistan}

\section{INTRODUCTION}

China Pakistan Economic Corridor (thereafter CPEC) is an important part of the construction of "The Belt and Road", and is also the demonstration project under $\mathrm{B} \& \mathrm{R}$. With the rapid growth of China's economy and the remarkable enhancement of its economic strength, China's foreign investment capacity and investment scale have been greatly improved. At present, an all-around and omni-directional strategic partnership has been established between China and Pakistan, which has laid a good political foundation for the construction of the CPEC. However, Pakistan's economy is relatively backward due to the capital shortage and weak infrastructure and industrial development. "Political heat but Economy cold" has been an issue between the two countries [1].

Pakistan is the friendliest relationship with China in South Asia. It is of great strategic significance to study China's investment in Pakistan. From the political strategy side, expanding the investment to Pakistan will help to strengthen economic cooperation since economic ties to the political relations, which is of great significance to the establishment of strategic partnership between countries in the process of game in. In terms of economic strategy, the construction of China Pakistan Economic Corridor is bound to involve Sino-Pakistan investment activities, and China's investment in Pakistan will have multiple-economic significance.

This paper will analyze the status quo of FDI and foreign trade between China and Pakistan, and try to find how FDI has an impact on foreign trade using the foreign trade data from 2008 to 2016. In the end, some suggestions will put forward according to the existing investment problems between two countries.

\section{LITERATURE REVIEW}

\section{A. Foreign Investment Theories}

Hymer [2], for the first time, put forward the theory of monopoly advantage, which started the research of international investment theory and made a good explanation for the investment of multinational enterprises in western developed countries. However, it cannot explain the location choice of multinational enterprises in the process of foreign investment, nor can it explain the outward investment behavior of developing countries, especially the behavior of developing countries' investment in developed countries and regions. Buckley \& Casson [3]raised internalization theory which explained the motivation of company' investment. Product life theory [4] and the marginal industry expansion theory [5] focus on the competitive advantage side of the foreign investment. When the globalization hits the world, Jiang [6] believed that the traditional theory of labor division, such as competitive advantage and factor endowment still fits the foreign investment. Song [7] analyzed the import impact on FDI and concluded that Multi-national companies can reduce the trade obstacles and variable costs through FDI and export will lead to the development of FDI.

\section{B. The Research of China's FDI in Pakistan}

Song [8] analyzed the energy investment risks in Pakistan based on Pakistan's social economy, energy environment and resources conditions. Tian and Yang [9] pointed out that the shortage of electricity has limited the economy development and give some suggestions for the Chinese companies to invest in Pakistan's water and electricity market. Besides the nature resources that impact China's FDI in Pakistan, institutional risk also impact the two countries. Pakistan has a high risk of terrorism and to promote the healthy development of China's FDI, Pakistan and China need to strengthen the cooperation in counter-terrorism and expand the dimension of diplomatic cooperation [10]. The overall investment in Pakistan is relatively loose and it is better for the Chinese companies to invest by means of M\&A and Green Field Investment [11]. 


\section{The Status Quo OF ChINA-PASKISTAN DiRECT INVESTMENT AND FOREIGN TRADE}

\section{A. The General Trade Profile between China and Pakistan}

It is seen from Table I that since 2008, China has been consistent trade surplus to Pakistan. The export volume has increased from 6.05 billion to 17.23 billion during 2008-2016. It is noted that the growth rate is much more significant after the proposal of B\&R and CPEC. Until 2016, China is Pakistan's biggest trade partner and Pakistan is China's second biggest trade partner in South Asia, following India. In 2016, the main products that China exports to Pakistan are concentrated on chemicals and related products, manufactured goods, machinery and transport equipment. While beverage and tobacco and manufactured goods are the main goods that China imported from Pakistan.

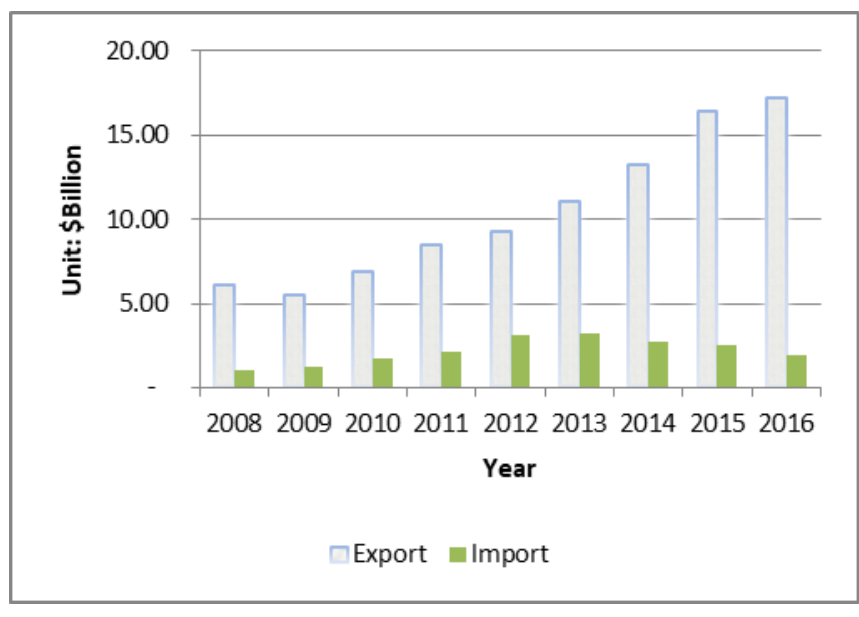

Fig. 1. China's trade volume to Pakistan

\section{B. Status Quo of China's FDI to Pakistan}

Right now, the CPEC is being promoted and the cooperation projected between the two countries is being gradually implemented. On Jan 29th 2018, Gwadar Economic Free Zone opened for business, which demonstrated a cornerstone of the CPEC. The ongoing modernization of the railway system from Karachi to Peshawar and Khunjerab to Gwadar, upgrading of road network, building of necessary infrastructure, building of power projects and setting up of special economic zones are still being undertaken. China has become the biggest FDI inflow country for Pakistan, with $\$ 1,185.6$ million in 2016. Half of the Chinese companies invest in infrastructure and power construction, and the way they invested includes BOT, Greenfield Investment and M\&A.

TABLE I. FDI INFLOWS IN PAKISTAN (\$MILLIONS) TABLE STYLES

\begin{tabular}{lrrrrrrr}
\hline Country & $\mathbf{2 0 1 0}$ & $\mathbf{2 0 1 1}$ & $\mathbf{2 0 1 2}$ & $\mathbf{2 0 1 3}$ & $\mathbf{2 0 1 4}$ & $\mathbf{2 0 1 5}$ & $\mathbf{2 0 1 6}$ \\
\hline USA & 238.1 & 227.7 & 227.1 & 212.1 & 223.9 & 13.2 & 71.1 \\
UK & 207.1 & 205.8 & 633 & 157 & 169.6 & 151.6 & 68.9 \\
U.A.E & 284.2 & 36.6 & 22.5 & -47.1 & 213.6 & 109.7 & 55.8 \\
Japan & 3.2 & 29.7 & 30.1 & 30.1 & 71.1 & 35.4 & 45.2 \\
Hong Kong & 125.6 & 80.3 & 242.6 & 228.5 & 136.2 & 93.3 & 25 \\
Switzerland & 110.5 & 127.1 & 149 & 209.8 & -6.5 & 58 & 16.9
\end{tabular}

\begin{tabular}{lrrrrrrr} 
Saudi & 6.5 & -79.9 & 3.2 & -40.1 & -64.8 & 24 & 1.9 \\
Arabia & 21.2 & 27.2 & 5.5 & -5.7 & -18.2 & -10.6 & -5.2 \\
Germany & 7.7 & 25.4 & 25.8 & 24.4 & 14.3 & 4 & 7.8 \\
South & -48 & -275 & -258 & -21.6 & 2.7 & 172.5 & -12.6 \\
Korea & 47.4 & 126.1 & 90.6 & 695.8 & 319.1 & 1064 & 1186 \\
Norway & \multicolumn{7}{c}{ DATA SOURCE: PAKISTAN BOARD OF INVESTMENT } \\
China & \multicolumn{7}{c}{. }
\end{tabular}

\section{THE ANALYSIS OF CHINA FDI'S IMPACT ON BILATERAL TRADE}

From the previous chapter's analysis of Sino-Pakistan FDI and foreign trade, it is concluded that both FDI and trade volume show fluctuating growth relations. In this part, it will use empirical analysis to test whether China's FDI to Pakistan will have effect on the bilateral trade.

\section{A. Research Hypothesis}

When investing in the host country, home country's import from host country will be promoted. Most Chinese companies invest in the labor intensive industry in Pakistan because of the higher home country labor costs. After the production in Pakistan, it will be imported back to China for further processing assembling. When China expands its FDI in Pakistan, it will reduce its import from Pakistan. That is because instead of importing natural resources from Pakistan for production, China will directly conduct its production in the terms of FDI. Accordingly, this paper proposes Hypothesis 1:

H1: China's FDI will positively promote China's import to Pakistan.

When investing in the host country, home country will promote the export to host country. The FDI China made to Pakistan will advance Pakistan to import the technical equipment, electronic equipment and management experience from China. On the other hand, when the home country invests in the host country, it will decrease its export since the production in host country satisfied the needs and therefore reduce the import from home country. So the Hypothesis 2 is put forward.

H2: China's FDI will positively promote China's export to Pakistan.

\section{B. Sample Selection and Data Resources}

CPEC was proposed by Prime Minister Li Keqiang in 2013, therefore this paper will choose the data from 2003 to 2016. The FDI data are from Statistical bulletin of China's FDI and the foreign trade data are retrieved UN Comtrade database.

\section{Model Introduction and Variable Design}

Based on Aberg's [12] model on FDI's relations with foreign trade, we can establish the following regression models:

\section{Ln EXt $=\alpha 1+\beta 1$ LnOFDIFt $+\beta 2$ LnOFDISt $-1+\varepsilon 1$ \\ Ln IMt $=\alpha 2+\beta 3$ LnOFDIFt $+\beta 4$ LnOFDISt $-1+\varepsilon 2$}

EXt represents the current year China's export to Pakistan while IMt represents the current year import from Pakistan. OFDI Flows and OFDI Stock are chosen to evaluate the 
China's FDI to Pakistan. OFDIFt is the current year OFDI flow and OFDISt-1 is previous year OFDI Stock.

\section{DATA ANALYSIS}

\section{A. Descriptive Statistic}

Taking the Export, Import, OFDI Stock and OFDI Flow of China to Pakistan as sample from 2008 to 2016, 36 observations are recorded. The results of survey samples are as follows: the mean of China's Export to Pakistan is $\$ 10.46$ million and the maximum incurred in 2016 , which is $\$ 17.23$ million. On the other hand, the mean of China's Import from Pakistan is $\$ 2.18$ million and the maximum number was in 2013 , which is $\$ 3.20$ million. The mean of OFDI stock and flows are \$2,653 million and \$358 million respectively. It can be seen that 1,014 million inflows was made to Pakistan in 2014, which was the largest inflows in 9 years. Both OFDI Stock and Export witnessed growth from 2008 to 2016, however, although experienced some fluctuation, Import and OFDI Flows' overall trend is upward.

\section{B. ADF Test}

For the reason that time series data are chosen for this study, ADF test will be conducted in order to ensure the effectiveness of the data before the regression analysis. ADF test is shown below using Eviews.

TABLE II. ADF TEST FOR THE VARIABLES

\begin{tabular}{|l|r|r|r|}
\hline \multirow{2}{*}{\multicolumn{1}{|c|}{ Variable }} & \multirow{2}{*}{$\begin{array}{c}\text { ADF Test } \\
\text { Statistics }\end{array}$} & $5 \%$ & $10 \%$ \\
\cline { 3 - 4 } & & -3.1483 & -2.7180 \\
\hline Ln OFDIF & -3.860321 & -3.1483 & -2.7180 \\
\hline Ln OFFIS & -4.338050 & -3.1483 & -2.7180 \\
\hline Ln IM & -2.847302 & -3.1483 & -2.7180 \\
\hline Ln EX & -3.299640 & & \multirow{2}{*}{ Critical Value } \\
\hline
\end{tabular}

It can be seen that 4 variables, which are OFDIF, OFDIS, Import and Export, are stable at $10 \%$ level in the case of logarithm.

\section{Regression Analysis}

OLS analysis was done for the 2 models using Eviews. The regression results are shown below.

The coefficient for LnOFDIF is negative while LnOFDISt1 is positive, which shows the OFDI Flow has a negative effect on import. OFDI Flows's effect on import is mainly on the short term while OFDI Stock is on the long term. In addition, OFDI Stock' positive impact on Import is significant at $1 \%$ level.

\begin{tabular}{|c|c|c|c|c|}
\hline \multicolumn{5}{|c|}{$\begin{array}{l}\text { Dependent Variable: LNIM } \\
\text { Method: Least Squares } \\
\text { Date: } 04 / 24 / 18 \text { Time: } 08: 42 \\
\text { Sample: } 20032016 \\
\text { Included observations: } 14\end{array}$} \\
\hline Variable & Coefficient & Std. Error & t-Statistic & Prob. \\
\hline C & 4.983111 & 0.412851 & 12.07001 & 0.0000 \\
\hline LNOFDIF & -0.083049 & 0.068448 & -1.213319 & 0.2504 \\
\hline LNOFDIS & 0.395577 & 0.094195 & 4.199553 & 0.0015 \\
\hline R-squared & 0.786223 & \multicolumn{2}{|c|}{ Mean dependent var } & 7.283577 \\
\hline Adjusted R-squared & 0.747355 & \multicolumn{2}{|c|}{ S.D. dependent var } & 0.5874 \\
\hline S.E. of regression & 0.295290 & \multicolumn{2}{|c|}{ Akaike info criterion } & 0.585692 \\
\hline Sum squared resid & 0.959159 & \multicolumn{2}{|c|}{ Schwarz criterion } & 0.722633 \\
\hline Log likelihood & -1.099847 & \multicolumn{2}{|c|}{ F-statistic } & 20.22780 \\
\hline Durbin-Watson stat & 0.633524 & \multicolumn{2}{|c|}{ Prob(F-statistic) } & 0.000206 \\
\hline
\end{tabular}

Fig. 2. Sino-Pakistan OFDI'S import effect

\begin{tabular}{|c|c|c|c|c|}
\hline \multicolumn{5}{|c|}{$\begin{array}{l}\text { Dependent Variable: LNEX } \\
\text { Method: Least Squares } \\
\text { Date: 04/24/18 Time: 08:45 } \\
\text { Sample: } 2003 \text { 2016 } \\
\text { Included observations: } 14\end{array}$} \\
\hline Variable & Coefficient & Std. Error & t-Statistic & Prob. \\
\hline C & 6.104754 & 0.326863 & 18.67678 & 0.0000 \\
\hline LNOFDIF & -0.053951 & 0.054192 & -0.995563 & 0.3409 \\
\hline LNOFDIS & 0.434335 & 0.074576 & 5.824031 & 0.0001 \\
\hline R-squared & 0.898796 & \multicolumn{2}{|c|}{ Mean dependent var } & 8.793278 \\
\hline Adjusted R-squared & 0.880395 & \multicolumn{2}{|c|}{ S.D. dependent var } & 0.676002 \\
\hline S.E. of regression & 0.233788 & \multirow{2}{*}{\multicolumn{2}{|c|}{ Akaike info criterion }} & 0.118605 \\
\hline Sum squared resid & 0.601225 & & Schwarz criterion & 0.255546 \\
\hline Log likelihood & 2.169767 & \multicolumn{2}{|c|}{ F-statistic } & 48.84564 \\
\hline Durbin-Watson stat & 0.603999 & \multicolumn{2}{|c|}{ Prob(F-statistic) } & 0.000003 \\
\hline
\end{tabular}

Fig. 3. Sino-Pakistan OFDI's export effect

The coefficient for LnOFDISt-1 is positive while LnOFDIF is negative, which shows the OFDI Stock has a positive effect on export. OFDI Stock's effect on trade is mainly on the long term while OFDI Flows is on the short term. In terms of the significance, OFDI Stock' impact on export is significant at $1 \%$ level.

\section{Summary}

From the above analysis, both two model are better fitted since the R2 value are around $80 \%$.

OFDI Stock is positively correlated with the import volume. Every 1\% increase of China's FDI Stock in Pakistan, China's import from Pakistan will increase by $39.55 \%$. On the other hand, every $1 \%$ increase of China's FDI Flow in Pakistan, China's import from Pakistan will decrease by $8.3 \%$. This trend demonstrates that in the beginning of the OFDI to Pakistan, the import effect is not explicit, while in the long term, FDI will promote the import volume after the FDI companies have experienced some advancement. So $\mathrm{H} 1$ is validated.

OFDI Stock is also positively correlated with the export volume. Every 1\% increase of China's OFDI Stock, the export to Pakistan will increase by $43 \%$, which shows that in the long term, China's FDI will have a positive impact on its export to Pakistan. Therefore, $\mathrm{H} 2$ is verified. 


\section{CONCLUSION}

From the above empirical analysis, it is obvious that China's FDI in Pakistan has a complementary relationship with Sino-Pakistan trade in the long term. Under the development of B\&R and CPEC, there will be more and more Chinese emprises investing in Pakistan. However, there are still some problems existed. Suggestions will be given to improve SinoPakistan investment and trade cooperation.

To begin with, cooperation in the infrastructure field should be strengthened. Infrastructure building includes transportation, energy, communication, urban construction, etc. The improvement of the infrastructure will promote trade and investment facilitation. Facilitation of the trade and investment is the key of B\&R and CPEC success. At present, Pakistan's infrastructure is lagging behind. The annual economic losses caused by infrastructure bottlenecks to Pakistan account for $4 \%$ - 6\% of its GDP. Yet Pakistan lacks capital and technology. The government hopes to solve this problem by attracting private investment and foreign investment. On the other hand, China has rich experience and capital and technology advantages in infrastructure construction such as transportation, energy and communication. In the future, Chinese enterprises should strengthen cooperation with Pakistan in the field of infrastructure, and strive to improve Pakistan's investment environment and boost productivity cooperation.

In addition, it is also important to strengthen the cooperation in the field of security. Pakistan's security problems are complex and various terrorist attacks have been frequent, making security issues an important factor affecting the investment and economic growth of Pakistan. But with the power of Pakistan alone, it is difficult to achieve the safety guarantee for CPEC. Especially for terrorist attacks, Pakistan's has limited control, which requires both sides to strengthen cooperation, develop a coordinated and consistent counterterrorism policy, combat all kinds of terrorist activities jointly, and provide reliable security for investment and common development of the two countries. For the current investment projects that Chinese companies conducted in Pakistan, it is critical to improve bilateral security evaluation and cooperation to face the non-traditional security threats. In addition, China should encourage more security enterprises to go out and cooperate closely with the security forces in Pakistan to release more security resources and jointly safeguard the property security and personnel safety of the Chinese companies in Pakistan

Last but not least, the investment methods should be diversified. All along, China's FDI in developing countries mainly adopts the way of project contracting. The main investment area of China in Pakistan is still engineering contracting in the field of infrastructure construction. In the beginning of the CPEC, due to the undeveloped situation of Pakistan domestic infrastructure, it is inevitable and reasonable for China to adopt this way. However, it is important to focus on the diversification of investment methods and to change the investment from engineering contracting to trade processing and to guide the Sino-Pakistan relations from simple trade relations to durable investment. China is now transiting to the economic new phase and facing the excess capacity transfer. It will be beneficial for China to gain competitive advantage in processing trade and produce more high-value added products. Direct investment can be used for the manufacturing industry in Pakistan, which will help Chinese companies make internationalized industry transfer, expand the trade market and bring real productivity to Pakistan and increase the employment opportunities.

\section{ACKNOWLEDGEMENT}

I would like to extend to sincere thanks to my $\mathrm{PhD}$ supervisor Dr. Liu Ersi, who give his insights on the topic selection of this paper and provide guidance through the review process. And also thanks to the reviewers who provide constructive feedbacks to this paper.

\section{REFERENCE}

[1] Chen Lijun and Liu Man, "The Capacity Cooperation under ChinaPakistan Economic Corridor Construction", Yunnan Social Science, (2), 2017, pp.70-76

[2] Hymer S., "The Efficiency (Contradictions) of Multinational Corporations", American Economic Review, 1970, 60(2):441-448.

[3] Buckley P J, Casson M., "The Optimal Timing of Foreign Direct Investment", Economic Journal, 1981, 91(361):75-87.

[4] Vernon R. International investment and international trade in the product cycle[J]. International Economics Policies \& Their Theoretical Foundations, 1966, 8(4):307-324.

[5] Kojima K., "A Macroeconomic Approach to Foreign Direct Investment", Hitotsubashi Journal of Economics, 1973, 14(1):1-21.

[6] Jiang Xiaojuan, "Trends and Theoretical Issues of Globalization of Service", Economic Research Journal, (2), 2008, pp.4-18.

[7] Song Pengfei, "Literature Review on the Impact of Export on Foreign Direct Investment", Foreign Investment in China, (10), 2012, pp.36-37.

[8] Song Mingzhi and Wang Lijie, "Evaluation of Investment Risk in Pakistan Thar Coal Field", Coal Engineering, 1(9), 2012, pp. 133-136.

[9] Tian Tian and Yang Wei, "The Opportunity and Risk Analysis of Pakistan's Hydropower Investment", Sci-Tech\&Development of Enterprise, (14), 2014, pp.54-56

[10] Li Dongkun and Ying Zhongming, "The Relationship between Institutional Risk of Pakistan and China's FDI from the perspective of bilateral political relations", Social Sciences in Ningxia, 207(1), 2018, pp.31-33

[11] Zhang Wenli and Zhai Xueling, "The Agriculture Investment Cooperation Status Quo Between China and Pakistan”, Journal of International Economic Cooperation, (5), 2017 pp.39-43.

[12] Aberg P., "Japanese Export and Foreign Direct Investment", AsiaPacific Transitions, 2001, pp207-223. 